\title{
The Flora of Azulejos in Maranhão, Brazil
}

\author{
Leandro R. Menezes ${ }^{1}$, Alícia B. Ewerton ${ }^{1}$, Amanda L. Garcia ${ }^{1}$, Susana S. Dominici ${ }^{2}$, Fabiane R. Fernandes ${ }^{3}$, Lívia Flávia A. \\ Campos $^{2,3}$, Lucas C. Marinho ${ }^{1^{*}}$ \\ ${ }^{1}$ Departamento de Biologia, Universidade Federal do Maranhão, São Luís, Brazil. ${ }^{2}$ Programa de Pós-graduação em Design, \\ Universidade Federal do Maranhão, São Luís, Brazil. ${ }^{3}$ Departamento de Desenho e Tecnologia, Universidade Federal do \\ Maranhão, São Luís, Brazil. \\ *Ic.marinho@ufma.br
}

\begin{abstract}
The azulejo (tile) styles from the Iberian Peninsula and other regions in the New World are strongly influenced by Muslim aesthetics. Many of the azulejos in Maranhão, Brazil, depict plants and plant parts, but little is known about their species identity. In this paper, we investigated the origin of 94 plants species illustrated on the azulejos in Maranhão based on their phytomorphic elements. Among them, twenty-five were from Asteraceae and eight were from Rosaceae. Most of the pieces are of Portuguese origin and the illustrations on the azulejos show a European lifestyle. For Brazilians, there was certainly no sense of belonging since the illustrations depict characteristics that are different from what is seen locally. Although the phytomorphic illustrations do not reflect local flora, azulejos have become the most characteristic symbol of Maranhão. Our research provides a preliminary data base upon which future works can be based to propose new prints of Maranhão plants and create digital guides that link historical information with botanical identifications.
\end{abstract}

Resumo O estilo azulejar aplicado da Península Ibérica e outras regiões no Novo Mundo tem forte influência da estética muçulmana. Muitos azulejos no Maranhão, Brasil, retratam plantas e partes delas, mas pouco se sabe sobre a identidade das espécies retratadas. Neste trabalho, investigamos a origem de 94 espécies de plantas ilustradas nos azulejos do Maranhão com base em seus elementos fitomórficos. Entre eles, vinte e cinco eram de Asteraceae e oito de Rosaceae. A maioria das peças é de origem portuguesa e as ilustrações dos azulejos mostram um estilo de vida europeu. Para os brasileiros, certamente não havia sentimento de pertencimento, uma vez que as ilustrações retratam características diferentes do que se vê localmente. Embora as ilustrações fitomórficas não reflitam a flora local, os azulejos tornaram-se o símbolo mais característico do Maranhão. Nossa pesquisa fornece uma base de dados a partir da qual trabalhos futuros podem ser feitos para propor novas estampas de plantas maranhenses e criar guias digitais que relacionam informações históricas com identificações botânicas.

Received April 22, 2021

OPENひACCESS

Accepted August 30, 2021

DOI 10.14237/ebl.12.1.2021.1764

Published October 8, 2021

Keywords Ceramics, Portuguese flora, Botanical illustration, Tiles

Palavras-chave Cerâmica, Flora portuguesa, Ilustração botânica, Azulejos

Copyright (C) 2021 by the author(s); licensee Society of Ethnobiology. This is an open-access article distributed under the terms of the Creative Commons Attribution-NonCommercial 4.0 International Public License (https://creativecommons.org/licenses/by-nc/4.0), which permits non-commercial use, distribution, and reproduction in any medium, provided the original author and source are credited.

\section{Introduction}

The history and habits of a group of people can be investigated from the images they produce within the historical, social, political, and economic contexts in which they were created. Perhaps most prominently, the Greeks, Romans, and Egyptians used images to express feelings, their perception of the world, and nature (Costa and Carvalho 2011). Painting or sculpting elements from nature, especially plants, is an ancient habit throughout human history. A multidisciplinary approach to studying these objects can reveal much more than their shapes and colors.

Plants are underappreciated compared to animals in many aspects of people's lives. Wandersee and Schussler (2001) coined the term "plant blindness"- 
also referred to as plant awareness disparity (sensu Parsley 2020)—to describe "the inability to see or notice the plants in one's own environment" (Wandersee and Schussler 2001:3). Based on data from the state of Maranhão, Brazil, this kind of plant awareness disparity also occurs with the botanical elements on most Portuguese tiles, or azulejos. In other words, many studies have been conducted with azulejos as objects from a quantitative perspective of origins and preservation whereas there is little interest in the artistic elements, plant identities, and historical context of these azulejos.

The Data: Azulejos of São Luis Island

Azulejos are commonly found on the historical buildings in Maranhão (Lima 2012) especially on the São Luís Island (also known as Ilba Grande or Big Island). These buildings often trace back to the 18th and 20th centuries and are primarily constructed by the Portuguese.

As the capital of Maranhão, São Luís endured several rounds of colonization from the Portuguese, the French, and the Dutch. São Luís was first invaded by the Portuguese in the 16th century, who failed to colonize the area because of the resistance from Indigenous people. In 1612 the French founded the municipality of São Luís, in honor of King Louis IX, and maintained a friendly relationship with the Indigenous people. In 1615 the Portuguese reconquered the province, but the absence of slave labor and incipient agriculture made it difficult for the settlers to remain in the region, since the Portuguese who ventured into American lands needed slave labor for agricultural production. In 1641 the Dutch invaded but it was subsequently colonized by the returning Portuguese. Today, São Luís is recognized as an Architectural Heritage of Humanity and a national reference for facade azulejos (Pereira 2012).

The Historic Center of São Luís includes about 5600 properties listed by the government, with varied architectural styles (Fig. 1A-B, Figueiredo et al. 2012). Azulejos were first introduced to São Luís around 1778 (historian Domingos Vieira, in Silva Filho 1980), but they did not gain popularity until the 19th century. This sudden interest is attributed to the aesthetic improvement of the azulejos on facades used to protect houses from winter rains during six months of the year (Silva Filho 1998). Between 1843 and 1879, various shipments of Portuguese azulejos arrived on São Luís Island, of which about $90 \%$ came from Lisbon (Fig. 1C) and others came from Porto
(Alcântara 1980). In the 19th century when the azulejo production diminished in Portugal, some commercial houses resold azulejos from other European countries to Brazil (e.g., Germany, Belgium, France, the Netherlands, and England) (Castro and Oliveira 2012). These azulejos are also found in smaller quantities in Maranhão. Due to the historical value, diversity, and preservation, the United Nations Educational, Scientific and Cultural Organization nominated the Historic Center of São Luís as a Cultural Heritage of Humanity.

The Botanical Illustrations on the Azulejos

Gonçalves (2019:136) defined the term phytomorphic as an "ornament or decorative motif with morphological characteristics similar to plants". This term was later applied to wooden structures (Burlamaqui Neto 2019) and masonry (Fig. 1D). In other works (e.g., Correia 2005; Cardeira 2015; Casimiro and Sequeira 2018; Gonçalves 2019) this kind of ornamentation is also called vegetalista.

At the beginning of the 11th century, the paintings on the azulejos from the Iberian Peninsula and the New World reflected a strong influence of Muslim aesthetics (mudéjar) in that phytomorphic elements were mixed with geometric compositions (Casimiro and Sequeira 2018). Gonçalves (2019) attributed the improvement of geometric, symmetrical and phytomorphic patterns to the Muslim rubric of alcoranic prohibition of human illustrations in the works. Before the 16th century, azulejos in Portugal largely came from the Spanish-Moorish region and had colors applied as pigmented enamel. Many azulejos circulated in Portugal during that time came from Talavera, Spain. In the 17th century, the production of standardized Portuguese azulejos began to occur, including some with plant illustrations in their composition (Fares 2012).

Phytomorphic elements are present in relief or flat on azulejos. The relief azulejos usually have phytomorphic decorations with branches, flower buds and flowers. The malmequer (as the Portuguese call some flowers of the sunflower family) is commonly featured in this type (see Fig. 1D, Ferreira et al. 2012; Araújo 2015). On the other hand, flat azulejos are more common in Brazil (Gonçalves and Curval 2008; Lima 2012), painted by hand or decorated using a stamping technique (estampilha). These azulejos have a huge number of geometric and/or phytomorphic shapes (Araújo 2015). More abstract phytomorphic elements are referred to as stylized phytomorphic (or 


\section{Ethrobiolocy Letters Data, Methods \& Taxonomies}

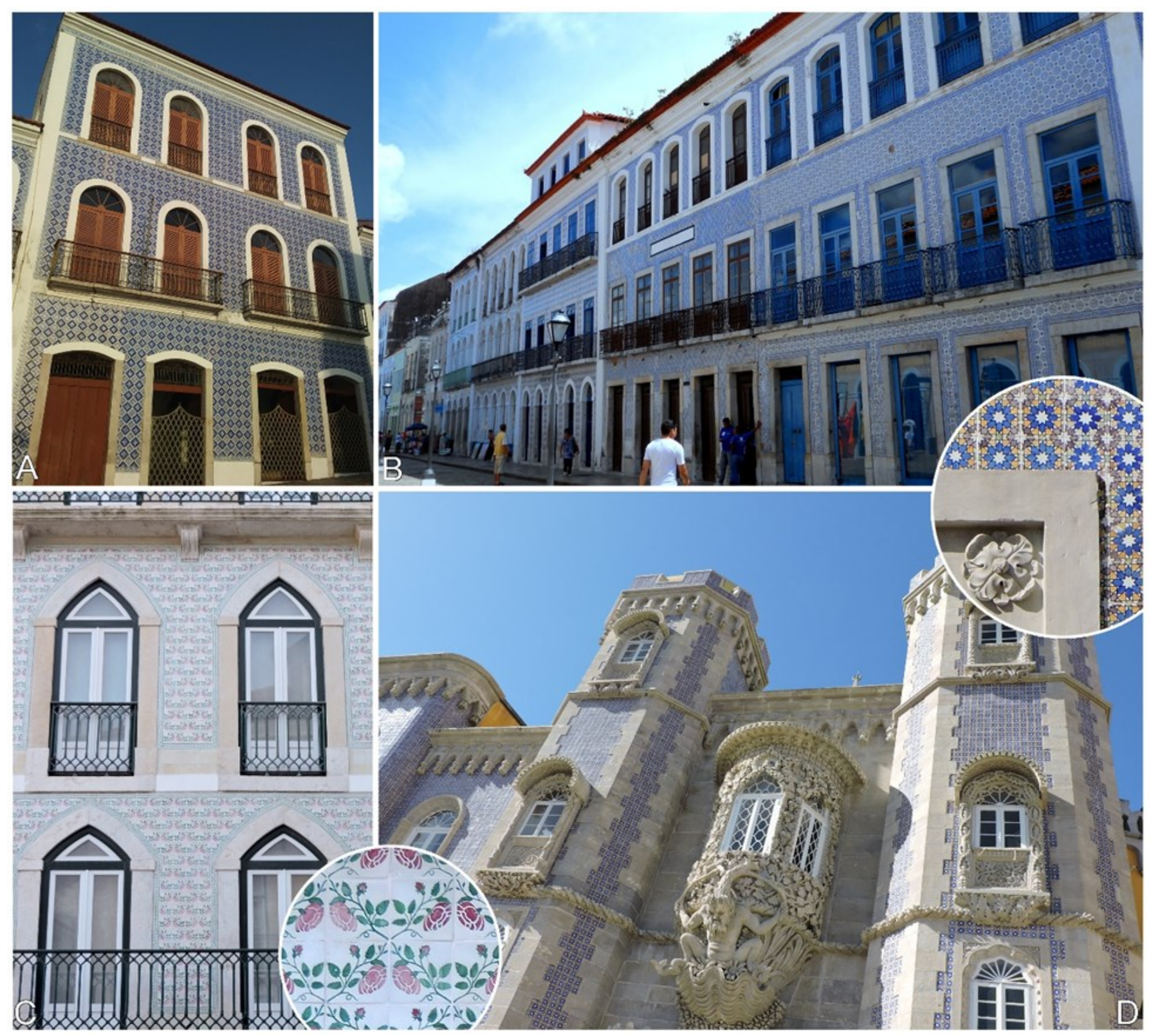

Figure 1 Tiled buildings in the Historic Center of São Luís, Maranhão, Brazil (A-B), and Portugal (C-D). Manor houses (Solares) A: on Estrela Street and B: on Portugal Street; C: Building in Lisbon, the detail shows the phytomorphic elements, leaves and flowers of roses; D: Pena Palace, Sintra, the detail shows the floral ornamentation, in masonry, on the edge of the window and azulejos with a phytomorphic element pattern. Photos: L.C. Marinho.

vegetalist) elements (Cardeira 2015), which connect and interact with geometric shapes that also make up the pieces.

\section{Phytomorphic Elements in Other Works}

Investigations of azulejo illustrations revealed the origin, production techniques, construction standards and state of conservation. Analysis of their content was little explored in Brazil. Chaud and Parreira (2020) created a panel of the Cerrado (a phytogeographic domain of Brazil) and installed at the Hospital das Clínicas at the Federal University of Goiás, Goiânia, Brazil. The panel illustrated the typical vegetation of this region, providing a public artistic experience that arouses the feeling of belonging. 
Costa et al. (2014) also investigated the fauna and flora on the azulejo panels of Colégio de Santo Antãoo-Novo, in Lisbon, Portugal. The authors recognized 44 animal and plant entities, of which trees, shrubs and herbs were the most diverse, although they were used only as decorative elements. Though not identified to the species level, common horticultural species such as cypresses, oaks, palms were recognized (Costa et al. 2014).

In addition to azulejos, plant forms are also used and investigated in other types of artwork. TeixeiraCosta et al. (2018) identified the plant species present in the stained-glass windows of the Dr. João Barbosa Rodrigues Botanical Museum, in São Paulo, Brazil, wrote a brief history of useful plants in Brazil, and identified six species of orchids in the central panel and another 28 species positioned around the central panel. Moreover, in the context of the Botanical Museum, Teixeira-Costa et al. (2018) discuss the relevance of these illustrations for the dissemination of scientific knowledge.

Lisbon's National Museum of Ancient Art (MNAA) published the itinerary for botanical iconography of its collection (MNAA 2020), in which approximate botanical identifications were made. In this report, MNAA briefly discussed the role of plants in Christian symbology, pagan gods (i.e., the work "Hércules capturando Cérbero" 1560-1561), and commercial activities (i.e., the work "O Descobrimento da Índia" 1504-1530).

The azulejos in Maranhão have been increasingly used for education and research, although there is still much more to be done with respect to the immaterial aspects of the azulejos: their relevance, beauty, history, and especially, what the azulejos represent for the people of Maranhão. This paper is the result of our research into the origin and identification of the species illustrated on azulejos in Maranhão. Our analyses are based on extensive literature searches and provide novel insights into: i) which botanical groups are most represented; ii) whether the plants are native or exotic to Brazil; iii) the origin of azulejos with phytomorphic decorative styles; iv) the relationship between the plants and the people who produced them; and v) the connection between these illustrated plants part of the culture of the people from Maranhão.

\section{Methods}

The Inventário do Patrimônio Azulejar do Maranhão by
Lima (2012, Inventory of the Tiled Heritage from Maranhão, in free translation) includes images of all azulejos on São Luís Island and in historic cities in the state of Maranhão, Brazil, as well as information on the location, state of conservation, origin, dimension, and technique of azulejo production. The images were examined to identify phytomorphic elements. After the first screening to locate the phytomorphic elements, we adopted the method of association and approximate identification, where images were compared to taxonomic groups from the countries of origin in order to identify them to the lowest possible taxonomic level. For Portuguese species, which are in greater numbers, the Flora-On: Flora de Portugal Interactiva (2014) website was used to compare Portuguese species with the illustrations.

\section{Results}

The Inventory of Tiled Heritage from Maranhão includes 452 types of azulejos, of which most are representations of religious themes and geometric shapes; only two pieces illustrate animals (swans). Among the 452 types, 94 azulejos $(\sim 21 \%)$ contain phytomorphic elements. 56 azulejos had their images associated with a botanical taxonomic group and seven images were identified to the species level. The remaining 31 pieces could not be identified to any specific taxonomic group. Many of illustrations were created with an artistic touch, and often using combined features from multiple species. The family Asteraceae (the sunflower family) was predominant and recognized in 25 azulejos, followed by Rosaceae (the rose family) with eight identified specimens (Fig. 2A).

Most of the pieces that have phytomorphic elements come from Portugal and England (Fig. 2B). The azulejos from Germany and England are most accurate with a wealth of details depicted by the decalcomania technique (Figs. 3E, G, H, 4B). This decoration technique gained its popularity in England in the middle to late 18th century. Asteraceae, Rosaceae (Fig. 3H) and Geraniaceae (the family of geraniums) were the most common families in British azulejos. Asteraceae (Fig. 4) and Geraniaceae (Fig. 3E) were the families represented in the German azulejos.

The botanical elements of the azulejos in Maranhão were especially rich in tapete-type and cercadura coverings. Tapete-type coverings are decorated azulejo panels, which are known for their repetition of colors and coverage of entire walls (Castro 2012). The outer bar forms a border (cercadura) of just one row of 


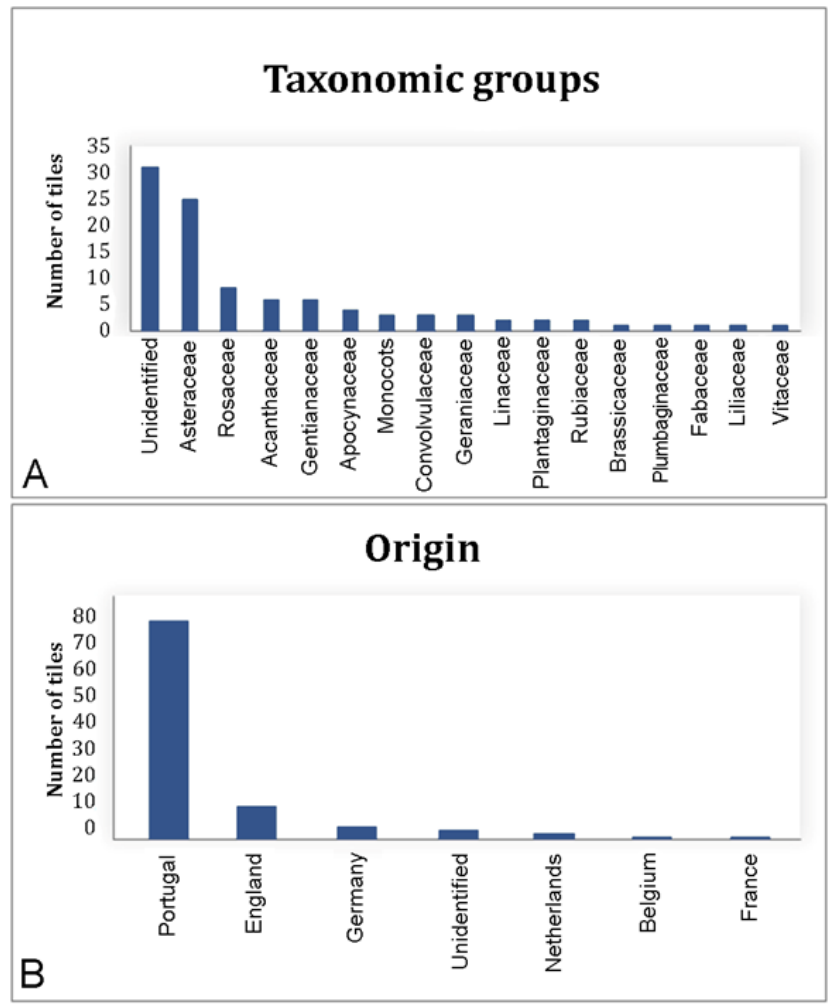

Figure 2 A: Taxonomic groups identified from illustrations on azulejos in Maranhão ( $N=452)$. B: Countries of origin of Maranhão azulejos that have phytomorphic elements in their illustrations.

azulejos that makes the covering look like a carpet (tapete). In the cercadura, it is common to find illustrations such as folhas-em-cadeia (leaves-in-chains) and renda-portuguesa (Portuguese lace).

\section{Discussion}

Among the 94 azulejos ( $21 \%$ of the total) with phytomorphic elements, 56 had images associated with a botanical taxonomic group and seven pieces were completely identified to the species level. Each of the seven pieces has at least one of the following three species: Rosa canina L. (rose); Vitis vinifera L. (grapevine); or Tulipa sylvestris L. (tulip). Although they occur in Brazil (Flora do Brasil 2020), rose and grapevine are cultivated species from the Old World. The only species of tulip grown in Brazil, Tulipa gesneriana L. (Dutilh and Campos-Rocha 2020), is not similar to the species illustrated on the azulejos. The azulejo that represents the family Liliaceae comes from Portugal (Fig. 3F) and the image is similar to Tulipa sylvestris, a species native of Portugal. The disposition of the leaves and the color used in the composition of the print were characteristic of Tulipa sylvestris (Fig. 3F).

Although most illustrations were identified to the family level, three pieces could be recognized only as monocots, a relatively broad taxonomic group, since there was not enough detail. When multiple plant species were presented in a single azulejo, the sunflower family Asteraceae was always one of them. In the middle of the 19th century, this family was common in relief azulejos and became the dominant decorative motif (Ferreira et al. 2012; Araújo 2015). Its dominance among prints can also be associated with the great diversity of the group, which has more than 25,000 species and a worldwide distribution, even in temperate countries. The arrangement of the

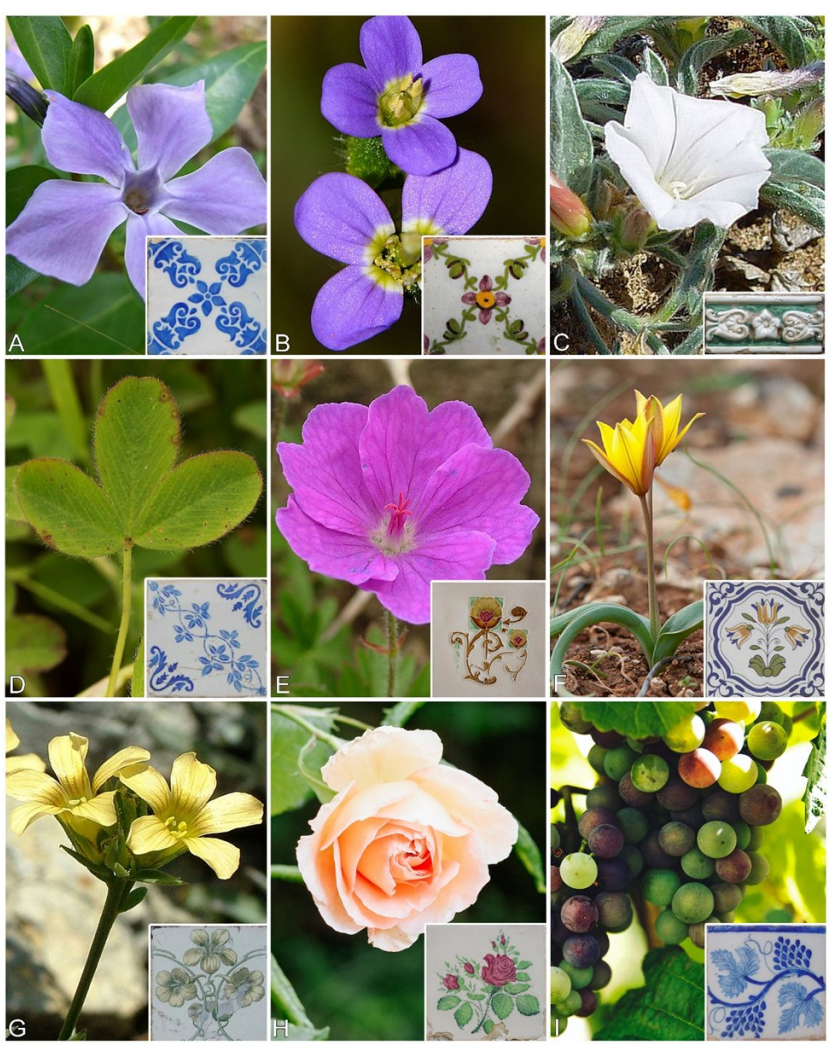

Figure 3 Examples of azulejos in Maranhão with phytomorphic elements and the corresponding plant group. A: Apocynaceae; B: Brassicaceae; C: Convolvulaceae; D: Fabaceae; E: Geraniaceae; F: Liliaceae; G: Linaceae; H: Rosaceae; I: Vitaceae. Photos: A,D,F: A.J.Pereira; B: P.V. Araújo; C: C.A. Aguiar; E,G: M. Porto; H: M. Henderson; I: R. Tandon. Azulejos from Lima (2012). A-G from FloraOn: Flora de Portugal Interactiva, distributed under Creative Commons license (CC BY 4.0); $\mathrm{H}-\mathrm{I}$ from Unsplash. 

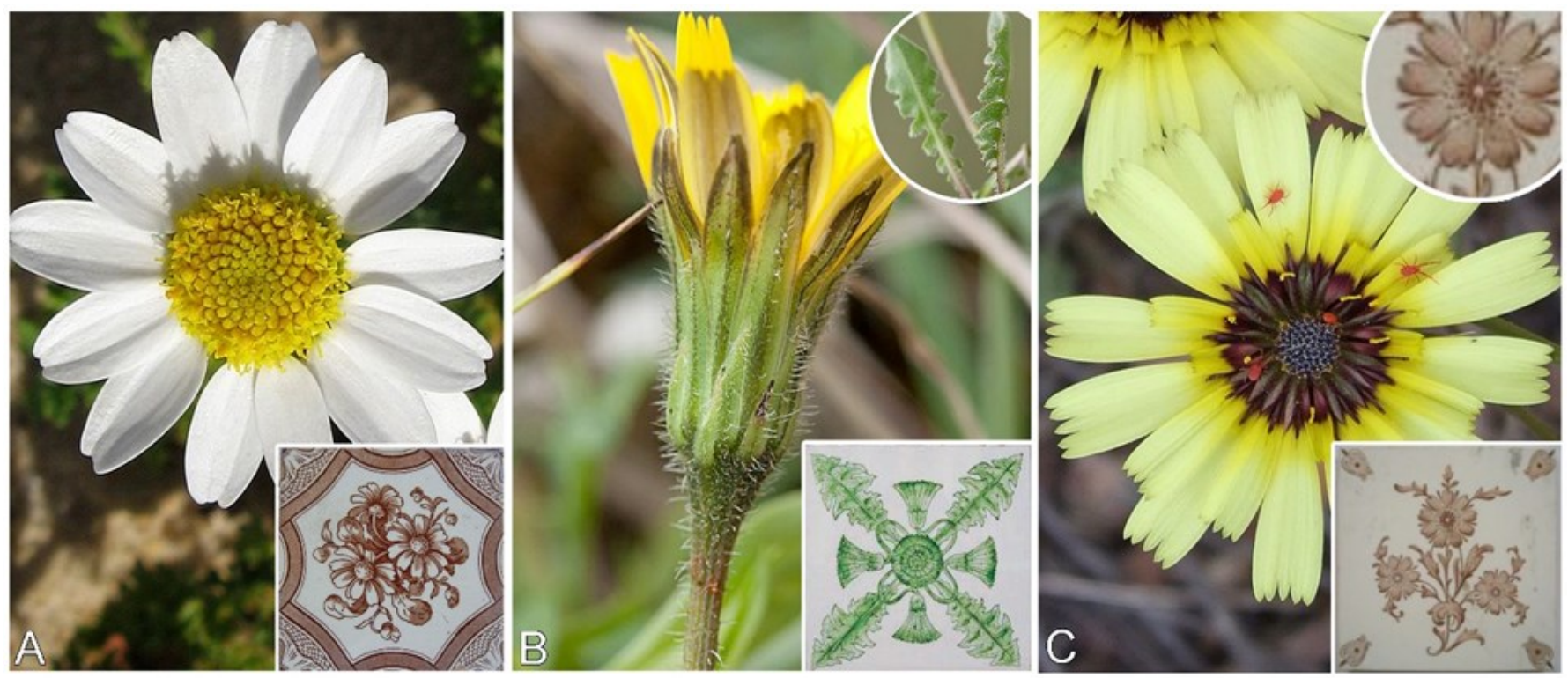

Figure 4 Examples of azulejos in Maranhão with illustrations of Asteraceae. Azulejos from Lima (2012). Photos: A,C: A.J.Pereira; B: M. Porto from Flora-On: Flora de Portugal Interactiva, distributed under Creative Commons license (CC BY 4.0).

ligulate flowers (flowers with fused petals in tongueshape) around a rounded disc with small tube flowers (see Fig. 4A, C) is typical of this family. In some prints flowers resembled a brush-like structure from the side view (see Fig. 4B). In these cases, there were usually compositions with leaves, which also made the identification easier.

Rosaceae ranked second (Fig. 2A) in abundance among azulejos $(\mathrm{n}=8$, Fig. $3 \mathrm{H})$. Their rose-like flowers and compound, serrate leaves are very characteristic of the family. All illustrations were related to Rosa canina, the most common rose species in cultivation. The number of petals illustrated differ from the native species of the genus. The genus Rosa has flowers with five petals, but the cultivated specimens have a proliferation of petals caused by the cultivation and manipulation of the morphology of crossings. It is common in cultivated species to design the morphology from crosses between specimens with desired characteristics.

The clear tendency was to illustrate plants that were observed and handled on a daily basis and had ornamental appeal, such as Asteraceae (Fig. 4), Rosaceae (Fig. 3H) and Liliaceae (Fig. 3F), and with economic value, such as Brassicaceae (cabbage and broccoli, Fig. 3C), Fabaceae (beans and soy, Fig. 3D) and Vitaceae (grapevine, Fig. 3I). This tendency provided another means for identification. Castro et al. (2014) also recognized that the azulejo panels at the Colégio de Santo Antão-o-Novo also illustrated everyday scenes, which have the most biological illustrations, including common plant species, such as cypresses, pine trees, grasses, and representatives of the family Cucurbitaceae (e.g., melons and pumpkins).

Many flowers are tetramerous (with four petals) in the shape of a cross (Fig. 3B). Although there was no additional evidence, this floral structure is commonly associated with family Brassicaceae (Fig. 3B). Species in this family have four petals arranged as a cross, which gives them their name Cruciferae. The economic importance of this clade as vegetables and garden ornaments makes this assumption coherent.

Our study demonstrates that the phytomorphic elements in the pieces are related to the countries of origin, mainly Portugal and England (Fig. 2B) even though some of the azulejos were produced after the diversity of Brazilian flora was known. This result is different from what was found by Teixeira-Costa et al. (2018) for the illustrations in the stained-glass windows of the Museum of the Botanical Institute of São Paulo, where all parts of the stained glass were produced in Brazil and, therefore, represent Brazilian species, with the exception of the fungus Amanita muscaria (L.) Lam. that is native to Asia and Europe.

The presence of approximately $20 \%$ of the azulejos with phytomorphic elements contrasts with 
the almost absence of animals represented on the pieces. Only two azulejos, of unknown origin, contain species of swans (Cygnus sp.), demonstrating that plant awareness disparity was not present during the production of azulejos. The representation of swans follows the same pattern as plants, since the swans are completely white and completely white swan species are not native to Brazil.

\section{Final Remarks: Azulejos, Plants and People}

For Brazilians, the phytomorphic illustrations on the azulejos in Maranhão did not provide a sense of belonging, since the elements are out of context with characteristics that differ from what is seen locally. This is not surprising because the azulejos were produced in Portugal, Germany, England, and other European countries. Despite colonizing various places in the world since the 15th century (Pataca 2016; Nogueira 2000; Linhares et al. 2018), the process of Portuguese territorial expansion occurred with greater intensity in the 19th century (Nogueira 2000; Linhares et al. 2018). In this way, it seems unlikely that exotic plant species were never of interest to the artists who designed azulejos. Ironically, throughout the colonization process, the plants illustrated on the azulejos were brought by the Europeans to Maranhão and had a long-term impact on the lives of local people. Many of these introduced species were naturalized in Brazil and used as medicine and food crops (Prazeres 1891; Linhares et al. 2019). Although the phytomorphic illustrations do not reflect local flora, azulejos have become the most characteristic symbol of Maranhão (Dominici 2021). Our research provides a preliminary data base upon which future works can be based to propose new prints of Maranhão plants and create digital guides that link historical information with botanical identifications.

\section{Acknowledgments}

We thank the Conselho Nacional de Desenvolvimento Científico e Tecnológico (CNPq-Brazil) for awarding undergraduate fellowships to $\mathrm{ABE}$ (grant \#112595/2020-0) and ALG (grant \#152701/2020-6). We also thank Patrícia Sperotto for helping with the illustrations of lianas and the Flora de Portugal Interactiva team for making images of plants in the field available. We also thank the anonymous reviewers for their invaluable contributions, and Dr. Liming Cai for critical reading of an earlier version of the manuscript.

\section{Declarations}

Permissions: The images from Flora-On: Flora de Portugal Interactiva are distributed under Creative Commons license (CC BY 4.0), and from Unsplash are distributed under Unsplash License. All authors agreed to participate and read the final version of the manuscript.

Sources of funding: None declared.

Conflicts of Interest: None declared.

\section{References Cited}

Alcântara, D. 1980. Azulejos Portugueses em São Luís do Maranhão. Fontana, Rio de Janeiro.

Araújo, S. I. S. B. 2015. A Conservação do Azulejo de Fachada na Cidade do Porto: As Práticas de Reabilitação de Edifícios com Fachadas Azulejadas. Master's thesis, Instituto Politécnico de Tomar, Porto, Portugal. Available at: https:// comum.rcaap.pt/handle/10400.26/13739.

Accessed on April 20, 2021.

Burlamaqui Neto, L. S. 2019. Um Éden nos Trópicos: As Projeções do Paraíso em um Móvel Colonial. Revista Investigações 32:410-426. Available at: https:// periodicos.ufpe.br/revistas/INV/article/ view/240511. Accessed on April 20, 2021.

Cardeira, A. Q. 2015. A Coleção de Azulejaria Antiga da Faculdade de Belas-Artes da Universidade de Lisboa. Master's thesis, Universidade de Lisboa, Lisboa, Portugal. Available at: https:// repositorio.ul.pt/handle/10451/23907. Accessed on April 20, 2021.

Casimiro, T. M., and J. L. Sequeira. 2018. Dois Conjuntos de Azulejos Hispano-Mouriscos. O Tejo e a Igreja do Senhor da Boa Morte (Século XVI). Cira-Arqueologia 6:243-253. Available at: https:// www.cm-vfxira.pt/cmvfxira/uploads/document/ file/2189/9.pdf. Accessed on April 20, 2021.

Castro, L. M. P. M. 2012. Tipo de Revestimento Azulejar. In Inventário do Patrimônio Azulejar do Maranbão, edited by Z. M. C. Lima, pp. 34-46. Santa Marta, São Luís, Maranhão.

Castro, L. M. P. M., and V. C. L. Oliveira. 2012. Procedência. In Inventário do Patrimônio Azulejar do Maranbão, edited by Z. M. C. Lima, pp. 52-54. Santa Marta, São Luís, Maranhão.

Chaud, E. M., and S. R. Parreira. 2020. Uma Janela para o Cerrado: Patureza e Arte. Botânica Pública 1:14-18. Available at: https://botanica.icb.ufg.br/ 
p/24641-botanica-publica-edicao-atual. Accessed on April 20, 2021.

Correia, L. N. 2005. Decoração Vegetalista nos Mosaicos Portugueses, Edições Colibri, Lisboa.

Costa, A. M., and R. S. Carvalho. 2011. A Floresta Antiga Admirada Entre Quatro Paredes. Iberne 88:18-19.

Costa, A. M., R. S. Carvalho, and L. M. Carvalho. 2014. A Fauna e a Flora nos Azulejos do Antigo Colégio de Santo Antão. Um Exemplo de Aprofundamento de Inventário. In $A$ Herança de Santos Simões: Novas Perspectivas para o Estudo da Azulejaria e da Cerâmica, edited by S. V. Flor, pp. 211 -237. Edições Colibri, Lisboa.

Dominici, S. S. 2021. Reconhecimento e Memória: Um Estudo Sobre Cegueira Botânica e os Azulejos do Centro Histórico de São Luís - MA. Master's thesis, Universidade Federal do Maranhão, São Luís, Brazil.

Dutilh, J. H. A., and A. Campos-Rocha. 2020. Liliaceae. In Flora do Brasil 2020. Jardim Botânico do Rio de Janeiro. [web page] Available at: http:// reflora.jbrj.gov.br/reflora/floradobrasil/FB610004. Accessed on April 20, 2021.

Fares, M., A. N. Pais, I. M. Martins, and S. M. Pereira. 2012. Azulejo Blues - An Analytical Study of the Blue Colours in Portuguese Azulejos. Report presented at Azulejar 2012, Aveiro, Portugal. Available at: https://core.ac.uk/display/29033094. Accessed on April 22, 2021.

Ferreira, L. M., A. L. Velosa, and J. Coroado. 2012. Património Azulejar em Centros Históricos, Desafios e Oportunidades para a Tradição Lusitânia. Report presented at Azulejar 2012, Aveiro, Portugal. Available at: http:// azulejar.web.ua.pt/congresso/congresso_pro.html. Accessed on April 22, 2021.

Figueiredo, M. G. S., H. Varum, and A. Costa. 2012. Azulejos de Fachada em São Luís do Maranhão. Report presented at Azulejar 2012, Aveiro, Portugal. Available at: https://core.ac.uk/ display/15570019. Accessed on April 22, 2021.

Flora do Brasil 2020. 2020. Jardim Botânico do Rio de Janeiro. [web page] Available at: http:// floradobrasil.jbrj.gov.br/. Accessed on April 22, 2021.

Flora-On: Flora de Portugal Interactiva. 2014. Sociedade Portuguesa de Botânica. [web page]
Available at: http://www.flora-on.pt. Accessed on April 22, 2021.

Gonçalves, L. F. C. 2019. A Circulação do Azulejo e Outras Cerâmicas Mudéjares nos Territórios da Expansão Ibérica: Breve Abordagem à Macaronésia e ao Novo Mundo. Master's thesis, Universidade da Madeira, Portugal. Available at: https:// digituma.uma.pt/handle/10400.13/2706. Accessed on April 22, 2021.

Gonçalves, M. R. F., and R. F. Curval. 2008. Azulejaria Portuguesa no Sul do Brasil. Métis: História \& Cultura 7:83-90. Available at: http:// www.ucs.br/etc/revistas/index.php/metis/article/ view/695/501. Accessed on April 22, 2021.

Lima, Z. M. C. 2012. Inventário do Patrimônio Azulejar do Maranbão. Santa Marta, São Luís.

Linhares, J. F. P., M. I. A. Rodrigues, P. F. Freitas, and C. U. B. Pinheiro. 2018. Etnobotânica Histórica das Plantas do Maranhão no Século XVII Baseada na Obra de Cristóvão de Lisboa. Biota Amazônia 8:15-18. DOI:10.18561/2179- 5746/ biotaamazonia.v8n3p15-18.

Linhares, J. F. P., M. I. A. Rodrigues, and C. U. B. Pinheiro. 2019. História Natural das Plantas do Maranhão (Brasil) no Século XIX Segundo a Obra do Frei Francisco de Nossa Senhora dos Prazeres. Boletim do Musen Paraense Emilio Goeldi. Ciências Naturais 14:209-221. Available at: https:// boletimcn.museu-goeldi.br/bcnaturais/article/ view/175. Accessed on August 06, 2021.

MNAA - Museu Nacional de Arte Antiga. 2020. Um Itinerário pela Iconografia Botânica. Lisboa. Câmara Municipal de Lisboa, Lisboa. Available at: http:// www.museudearteantiga.pt/educacao/atividadesatuais/lisboa-capital-verde-europeia-2020/umitinerario-pela-iconografia-botanica. Accessed on April 22, 2021.

Nogueira, E. 2000. Uma História Brasileira da Botânica. Paralelo 15, São Paulo.

Parsley, K. M. 2020. Plant Awareness Disparity: A Case for Renaming Plant Blindness. Plants, People, Planet 2:598-601. DOI:10.1002/ppp3.10153

Pataca, E. M. 2016. Coleta, Transporte e Aclimatação de Plantas no Império Luso-Brasileiro (1777-1822). Museologia \& Interdisciplinaridade 5:88-108. DOI:10.26512/ museologia.v5i9.17247.

Pereira, D. J. C. 2012. Histórico da Azulejaria. In Inventário do Patrimônio Azulejar do Maranbão, edited 
by Z. M. C. Lima, pp. 27-28. Santa Marta, São Luís, Maranhão.

Prazeres, F. F. N. S. 1891. Poranduba Maranhense: Relação Histórica da Província do Maranhão. Revista Trimensal do Instituto Histórico e Geographico Brazileiro 54:274-277. Available at: http:// biblio.etnolinguistica.org/

prazeres_1891_poranduba. Accessed on August 06, 2021.

Silva Filho, O. P. 1998. Arquitetura Luso-Brasileira no Maranhão. Formato, Belo Horizonte.
Teixeira-Costa, L., Y. V. Hirao and E. Hingst-Zaher. 2018. Ilustrações no Vitral do Museu do Instituto de Botânica de São Paulo. Cadernos de História da Ciência 12:186-208. DOI:10.47692/ cadhistcienc.2016.v12.33862

Wandersee, J., and E. Schussler. 2001. Towards a Theory of Plant Blindness. Plant Science Bulletin 47:29. Available at: https://www.botany.org/userdata/ IssueArchive/issues/originalfile/ PSB_2001_47_1.pdf. Accessed on April 22, 2021. 